\title{
Modified Judet's Quadricepsplasty with patella traction for extension contracture of knee
}

\begin{abstract}
To see the clinical result of Modified Judet's Quadricepsplasty (MJQP) with patella traction at BARI-ILIZAROV ORTHOPAEDIC CENTRE for the treatment of knee extension contracture.

Materials and methods: We received 16 patients with knee extension contracture treated by MJQP with patella traction from January 2015 to January 2021, at our BARI-ILIZAROV ORTHOPAEDIC CENTRE. The age at revision surgery was $25-58$ years. The time between fracture treatment to MJQP was 4 to 20 months and our follow up was 10-30 months. We assessed pre-operative and post-operative range of motion (ROM).

Results: Knee range of motion pre-operatively was 5-50 $(35 \pm 10)^{\circ}$ and 35-85 $(55 \pm 10)^{\circ}$ after MJQP and in average of $0-35(18+10)^{\circ}$. We applied patella traction for $12-14(10 \pm 3)^{\circ}$ days. When we removed the patella traction the knee range of motion at that time was 95-110 $(93 \pm 4)^{\circ}$ and increase of 10-70 compared with the range of motion after release of all arthrofibrosis in the joint. Our follow up time was 12-35 (19 \pm 5$)$ months. Knee range of motion at first follow up was 85-135 $(105 \pm 13)^{\circ}$, an increase of 45-105 $(70 \pm 15)^{\circ}$ compared with pre-operatively and of $10-45(12 \pm 12)^{\circ}$ compared with the range of motion after patella traction removed. Knee function was excellent in 12 cases $(70 \%)$, good in $3(27 \%)$ and fair in one $(3 \%)$.
\end{abstract}

Conclusion: MJQP with patella traction lengthens the contracted Quadriceps femoris gives excellent result with proper post-operative care and CPM therapy.

Keywords: Knee extension contracture, Patella traction, Modified Judet's Quadricepsplasty
Volume I 3 Issue 5 - 202 I

Bari MM,' Islam Shahidul, ${ }^{2}$ Azad Mohammad Abul Kalam, ${ }^{3}$ Ashraf Mohammad Tanvir, ${ }^{4}$ Bari A.M Shayan $\mathrm{R}^{5}$

IProf. Ph.D, Chief Consultant, Bari-Ilizarov Orthopaedic Centre, Visiting and Honored Prof., Russian Ilizarov Scientific Centre, Kurgan, Bangladesh

2Prof., Bari-llizarov Orthopaedic Centre, Bangladesh

${ }^{3}$ Assistant professor, Anesthesiology, Bangladesh Institute of Health Science (BIHS), Bangladesh

${ }^{4}$ Consultant, Orthopaedics, NITOR, Bangladesh

${ }^{5}$ Medical officer, Bari-llizarov Orthopaedic Centre, Bangladesh

Correspondence: Bari MM, Bari-llizarov Orthopaedic Centre, I/I, Suvastu Shirazi Square, Lalmatia Block E, Dhaka-I207, Bangladesh, Tel +880I8I921I595, Email bari.ilizarov3।@gmail.com

Received: October 04, 202। | Published: October 18, 202 I

\section{Introduction}

Extension contracture or stiff knee is a complication of femur fracture, particularly in the supracondylar region. After a fracture in the supracondylar region, we face difficulties in gaining full range of motion in the knee. Stiffness of the knee occurs due to periarticular and intramuscular adhesions. Severe stiffness can't be treated by conservative treatment followed by exercises. ${ }^{8}$

\section{The pathological conditions that limit knee flexion include:}
a) Arthrofibrosis
b) Contracture of the joint capsule.
c) Quadriceps muscle contracture.
d) Fascial contractures.

The knee extension contracture or knee sti ness requires surgical interventions in $15.5 \%$ of patients. The definition of knee extension is controversial, the criteria are
a. Decreased knee flexion $\left(<85^{\circ}\right)$
b. Limited knee range of motion $\left(<70^{\circ}\right)$
c. Increased knee flexion $\left(>15^{\circ}\right)$ and
d. Decreased knee flexion $\left(<75^{\circ}\right)$. ${ }^{1,2}$

Maintenance of adequate knee range of motion is essential for normal knee function. It has been proved by gait analysis that $65^{\circ}$ knee flexion is required for daily activities and for level walking, $83^{\circ}$ for stair ascent, $90^{\circ}$ for stair descent, $115^{\circ}$ for squatting or kneeling, and $94-105^{\circ}$ for rising from sitting to standing. ${ }^{3}$ A knee flexion angle of $110^{\circ}$ is required for daily life. The Bangladeshi people have a relatively greater necessity for knee flexion and squatting and sitting cross-legged are more common due to religion. That is why surgical intervention is necessary to increase the knee range of motion for Bangladeshi people.

Recent management for post-traumatic knee extension contracture include
a. Rehabilitation and physiotherapy,
b. Closed arthrolysis under anesthesia. ${ }^{8}$
c. Arthroscopic release. ${ }^{4}$
d. Quadricepsplasty. ${ }^{5}$

Quadricepsplasty includes:

a. Conventional quadricepsplasty,

b. Thompson and Judet techniques

c. Modified Judet's quadricepsplasty (MJQP) combined with Ilizarov frame ${ }^{6}$ needs high expertise. That is why till today no consensus on the best treatment for post-traumatic, postoperative knee extension contracture. The" Ilizarov law of tension-stress" is slow and steady traction on a living tissue creates a stress which is metabolically activated and which can stimulate histo-neogenesis. ${ }^{7}$ On the basis of that 
we tried to release the contracture of quadriceps femoris by patella traction. For the last 7 years at our BARI-ILIZAROV ORTHOPAEDIC CENTRE we treated post-operative knee extension contracture using the combination of MJQP with patellar traction to lengthen the contracted quadriceps femoris which improves knee function within a short period of time.

\section{Materials and methods}

Inclusion criteria:

(a) age $>20$ years, $\leq 62$ years,

(b) Anamnesis of femur fracture,

(c) pre-operative knee $\mathrm{ROM}$ was $\leq 50^{\circ}$,

(d) MJQP with patellar traction.

\section{Complications}

During our treatment, in one case cutting of patella by Kirschner's wire and necrosis was observed of the skin around the knee, and pin tract infection were also recorded. We measured the ROM by our orthopaedic team. By using goniometer, we measured the range of movement. The stationary arm was placed from the greater trochanter to the lateral condyle, and the movable arm was placed from the head of the fibula and the lateral malleolus.

\section{Surgical techniques}

Position of the patient in supine; we prefer spinal anesthesia. We recorded range of motion; flexion and extension after anesthesia. Our MJOP was performed in 2 steps surgery.

First, a lateral incision is made from the tibial tubercle which is extended through the lateral patella, up to distal $1 / 3$ of the femur. The fibrosis and adhesion were released in between the lateral patellar retinaculum and lateral femoral condyle. Through extended lateral incision medial retinaculum was released from the medial femoral condyle. If we see the medial lysis is incomplete and then a short incision was made in the medial patellar region.

Secondly, the extra-articular adhesions were released in between the quadriceps femoris and femur. By doing these two steps surgery we can get knee flexion in most of the patients. If we see by doing this two steps surgery knee flexion is not markedly increased, then we can go for third step of Judet's quadricepsplasty. If knee flexion is less than $90^{\circ}$ after two steps surgery it indicates that contracture of the quadriceps affecting the knee flexion. Then we apply patellar traction to lengthen the quadriceps femoris. $1.8 \mathrm{~mm}$ Kirschner wire was applied and direction of traction was vertically upward, and the heel of the affected limb was lifted above the bed. We applied traction on the operation table after operation and maintained until the knee range of motion exceeded $90^{\circ}$ and took 10 to 14 days; and at the same time $1.5 \mathrm{~kg}$ weight was applied on the dorsum of the affected ankle. The weight was adjusted in according to patient's need.

\section{Post-operative treatment}

According to the needs of the patient's we prescribed injection Voltalin -75 mgml, 1 ampule (intra-muscular)1/M 12 hours for 2 days and after that we prescribed oral as needed. The traction height was always adjusted in accordance with knee flexion gain each day. We routinely check the status of Kirschner's wire through the patella and clean with rectified spirit. During our follow up period we check the knee flexion and if it is $>90^{\circ}$, we maintained the traction for another 5 to 6 days and then we asked the physiotherapist to stop that moment. We use CPM for 2 times a day, each time for 10 minutes. Our physiotherapist doing physical exercise for 30 minutes each day. Before discharging the patient, we instruct them to follow our suggestions so that they can continue the exercises at home.

\section{Results}

From January 2015 to January 2020, 16 patients with knee extension contracture were treated by MJQP (Modified Judet's Quadricepsplasty). We applied patellar traction in all the patients. After doing 2 step surgery the khee Rom could not reach $90^{\circ}$. We followed up the patients and before doing surgery, we counselled the patients properly. In Table 1 you can see the outcome of the patients. The time between fracture fixation and MJQP was 5 to 25 $(20 \pm 5)$ months, and follow-up period was 12-15 (15 \pm 5$)$ months. The duration of patellar traction was 10 to 16 days. After removal of patellar traction, the knee ROM was 95-105 $(93 \pm 4)^{\circ}$. The knee ROM at final follow-up was $90-135(105 \pm 14)^{\circ}$. No wire tract infection were seen during the follow-up.

Table I Clinical data of the Patients who developed knee stiffness after surgery for distal femoral fracture

\begin{tabular}{|c|c|c|c|c|c|c|c|c|}
\hline Case & Gender & Age & Location & Fixation & $\begin{array}{l}\text { Time } \\
\text { (Months) }\end{array}$ & $\begin{array}{l}\text { Preoperative } \\
\left.\operatorname{ROM}^{\circ}\right)\end{array}$ & $\begin{array}{l}\text { After Modified } \\
\left.\text { Judet's ROM ( }{ }^{\circ}\right)\end{array}$ & $\begin{array}{l}\text { Knee } R O M \text { after } \\
\text { patella traction } \\
\text { release }\left({ }^{\circ}\right)\end{array}$ \\
\hline I & $M$ & 45 & Right & Ilizarov apparatus & 10 & 50 & 90 & 92 \\
\hline 2 & $M$ & 63 & Left & Plating and screw & 8 & 45 & 95 & 90 \\
\hline 3 & $M$ & 46 & Right & Plating and screw & 9 & 40 & 90 & 92 \\
\hline 4 & $M$ & 44 & Left & Plating and screw & 11 & 50 & 95 & 95 \\
\hline 5 & $M$ & 57 & Left & Interlocking I/M nailing & 12 & 45 & 90 & 92 \\
\hline 6 & $M$ & 62 & Right & Ilizarov apparatus & 9 & 50 & 90 & 90 \\
\hline 7 & $M$ & 59 & Left & Ilizarov apparatus & 10 & 35 & 90 & 92 \\
\hline 8 & $M$ & 48 & Left & Plating and screw & 8 & 40 & 95 & 92 \\
\hline 9 & $M$ & 65 & Right & Plating and screw & 7 & 45 & 90 & 92 \\
\hline 10 & $M$ & 49 & Left & Ilizarov apparatus & 13 & 50 & 100 & 94 \\
\hline $\mathrm{II}$ & $M$ & 58 & Right & Plating and screw & 8 & 30 & 90 & 92 \\
\hline
\end{tabular}


Table Continued...

\begin{tabular}{|c|c|c|c|c|c|c|c|c|}
\hline Case & Gender & Age & Location & Fixation & $\begin{array}{l}\text { Time } \\
\text { (Months) }\end{array}$ & $\begin{array}{l}\text { Preoperative } \\
\left.\text { ROM }^{\circ}\right)\end{array}$ & $\begin{array}{l}\text { After Modified } \\
\left.\text { Judet's ROM ( }{ }^{\circ}\right)\end{array}$ & $\begin{array}{l}\text { Knee } R O M \text { after } \\
\text { patella traction } \\
\text { release }\left(^{\circ}\right)\end{array}$ \\
\hline 12 & $M$ & 61 & Left & Ilizarov apparatus & 10 & 40 & 95 & 90 \\
\hline 13 & M & 60 & Right & Plating and screw & 9 & 50 & 90 & 92 \\
\hline 15 & $M$ & 46 & Right & Ilizarov apparatus & 12 & 20 & 100 & 92 \\
\hline 16 & $M$ & 52 & Left & Plating and screw & 13 & 30 & 90 & 92 \\
\hline
\end{tabular}

\begin{tabular}{|c|c|c|c|c|c|c|c|}
\hline Case & $\begin{array}{l}\text { Knee ROM after } \\
\text { passive stretch } \\
\text { rehabilitation }\left(^{\circ}\right)\end{array}$ & $\begin{array}{l}\text { Improvement } \\
\text { in Knee ROM } \\
\text { after release of } \\
\text { adhesions }\left({ }^{\circ}\right)\end{array}$ & $\begin{array}{l}\text { Duration } \\
\text { of patella } \\
\text { traction }\end{array}$ & $\begin{array}{l}\text { Improvement } \\
\text { in Knee ROM } \\
\text { after release of } \\
\text { adhesions }\left({ }^{\circ}\right)\end{array}$ & $\begin{array}{l}\text { Knee ROM } \\
\text { after atnal } \\
\text { follow up }\left({ }^{\circ}\right)\end{array}$ & $\begin{array}{l}\text { Follow } \\
\text { up period } \\
\text { (months) }\end{array}$ & Result \\
\hline I & 100 & 30 & 12 days & 30 & 95 & 6 & Excellent \\
\hline 2 & 100 & 25 & 13 days & 25 & 95 & 7 & Excellent \\
\hline 3 & 99 & 33 & 12 days & 33 & 93 & 6 & Excellent \\
\hline 4 & 100 & 30 & 10 days & 30 & 95 & 8 & Good \\
\hline 5 & 100 & 35 & 12 days & 35 & 95 & 7 & Excellent \\
\hline 6 & 98 & 30 & II days & 30 & 94 & 6 & Excellent \\
\hline 7 & 100 & 25 & I4 days & 25 & 95 & 8 & Excellent \\
\hline 8 & 95 & 30 & II days & 30 & 95 & 7 & Excellent \\
\hline 9 & 100 & 35 & I4 days & 35 & 95 & 6 & Excellent \\
\hline 10 & 100 & 20 & 12 days & 20 & 95 & 7 & Excellent \\
\hline 11 & 100 & 25 & 13 days & 25 & 92 & 8 & Good \\
\hline 12 & 100 & 20 & 10 days & 20 & 95 & 9 & Excellent \\
\hline 13 & 90 & 30 & 14 days & 30 & 95 & 8 & Good \\
\hline 14 & 100 & 30 & 14 days & 30 & 95 & 7 & Excellent \\
\hline 15 & 95 & 35 & 13 days & 35 & 95 & 6 & Fair \\
\hline 16 & 100 & 20 & I Idays & 20 & 100 & 9 & Excellent \\
\hline
\end{tabular}

\section{Discussion}

Patients with a high-energy trauma with massive soft tissue injuries may experience post-operative knee extension contracture. ${ }^{1,2}$ Why this knee contracture happens? Because of (1) adhesions of rectus femoris muscle to the femur; (2) adhesion between the patella and femoral condyles, and between tibial and femoral joints; (3) fibrosis and contraction of rectus femoris. Knee extension contracture usually treated by Thompson and traditional Judet's Quadricepsplasty. In Thompson procedure extension lag is obvious. In traditional Judet's
Quadricepsplasty, 5 steps surgery is need with big incisions. ${ }^{3}$ and lots of blood is needed. But in MJQP, surgery is not big. We shall have to release intra-articular adhesions in between quadriceps femoris and lower $1 / 3$ of the femur. We do not need to go for proximal release. After that patellar traction is applied with $1.8 \mathrm{~mm}$ kirschner's wire through to patella lengthen the contracture and adhesions of the quadriceps femoris. After 10-14 days of traction the average knee ROM was $93^{\circ}$, with a mean flexion gain of $40^{\circ}$ which suggests patellar traction lengthened the contracted quadriceps femoris. 


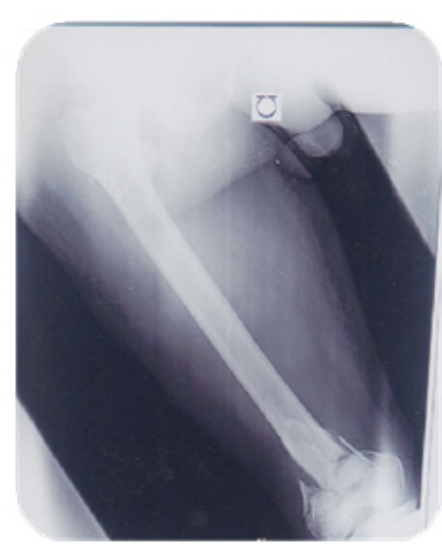

A

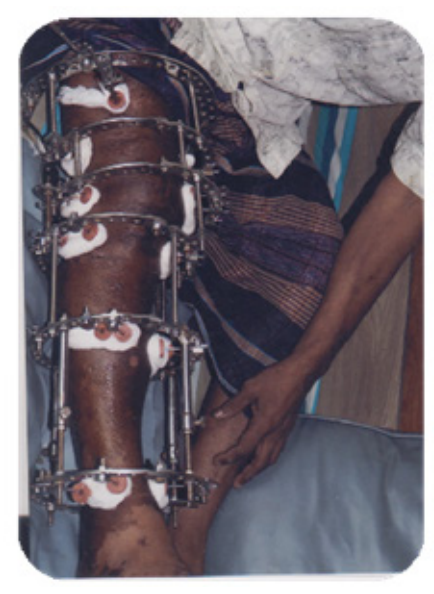

E

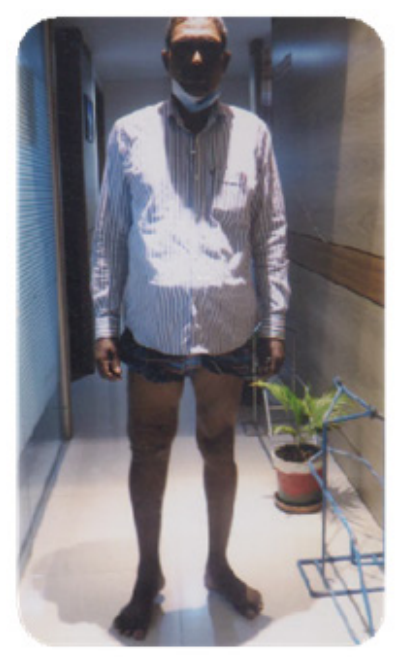

(1)

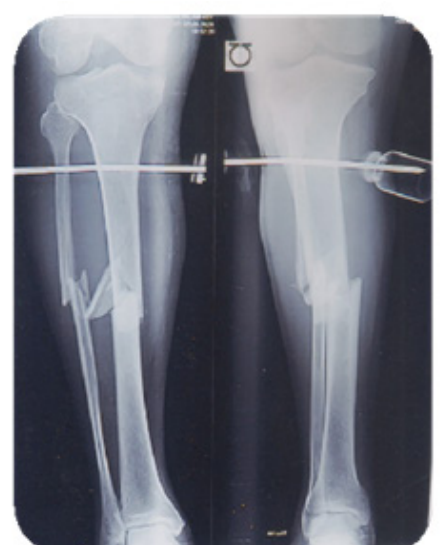

B

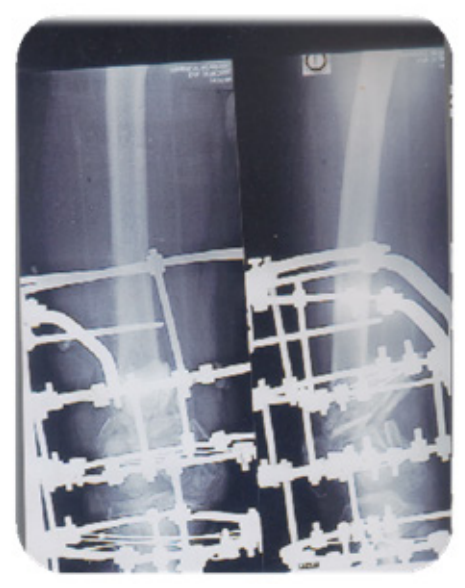

F

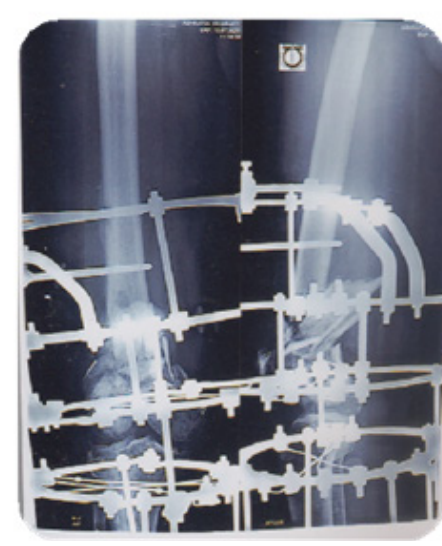

C

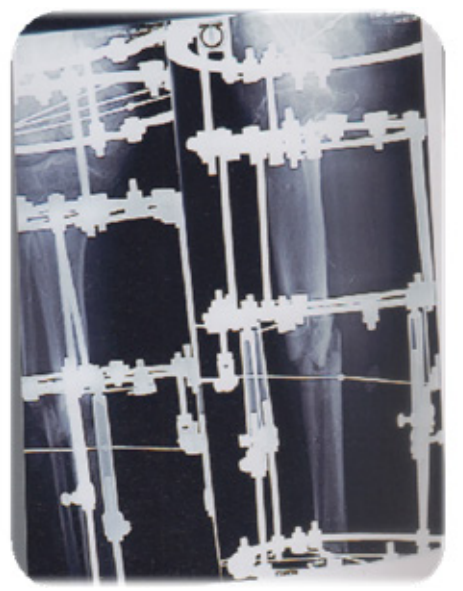

G

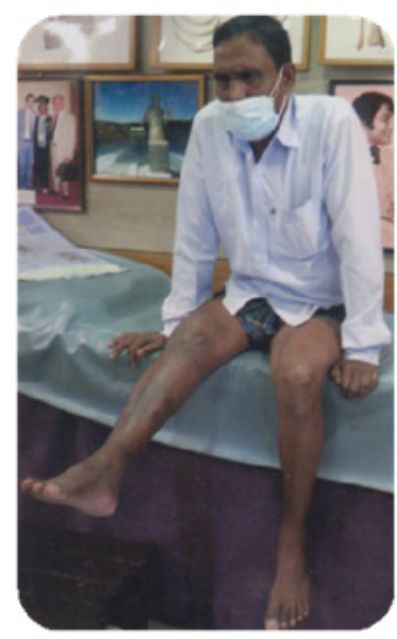

(1)

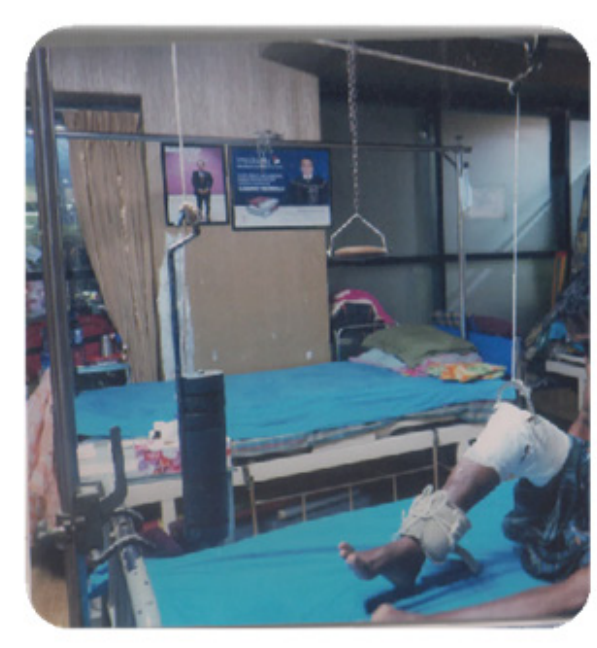

K

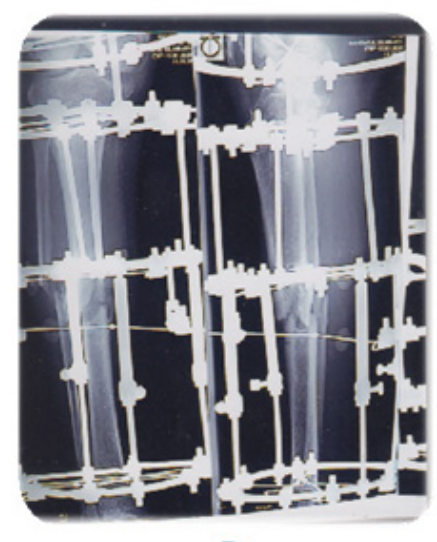

(D)

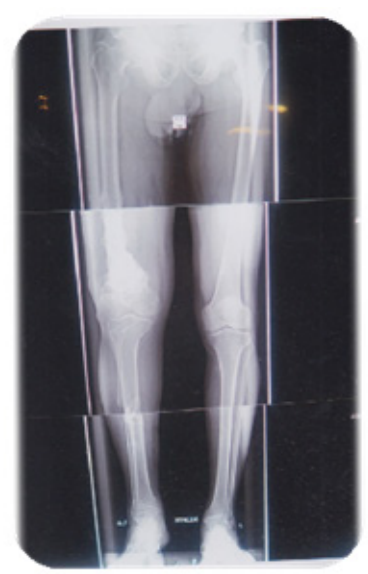

H)

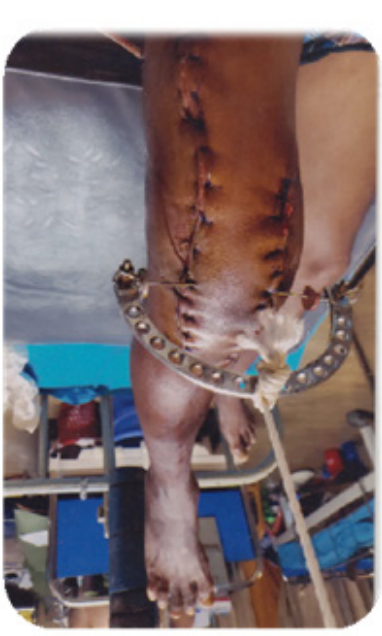

L 


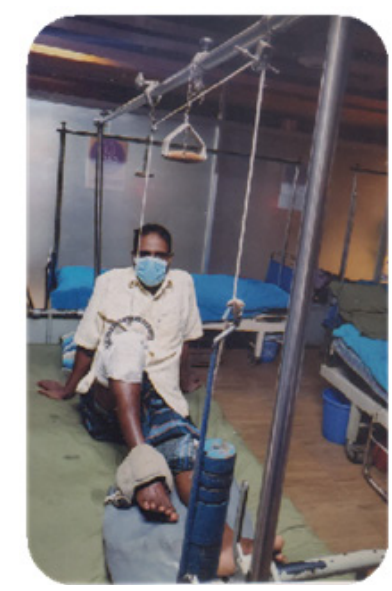

(M)

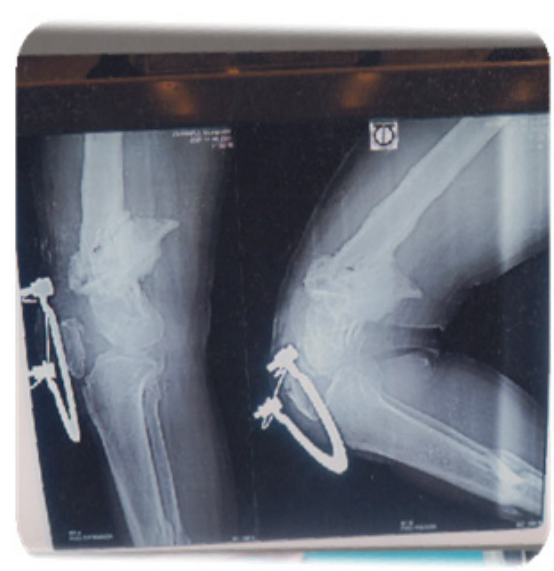

N

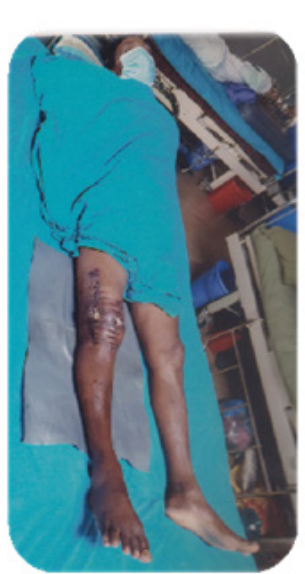

(O)

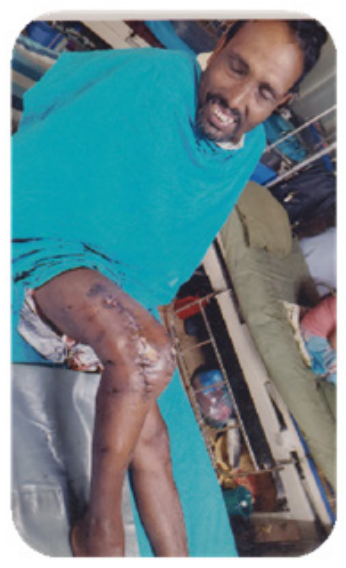

(

Figure I 45 years old man, Nonunion right lower femur with right tibia fibula, poat traumatic post-operative right knee extension contracture.

(A) Radiograph of fracture lower end of right femur.

(B) Same patient, tibia comminuted fracture.

(C) Radiographic view of femur, treated by llizarov technique.

(D) Radiographic view of tibia, treated by llizarov technique.

(E) External view of the llizarov apparatus.

(F) Radiographic view of femur after 3 months follow up.

(G) Radiographic view of tibia after 3 months follow up.

(H) Radiographic view of femur and tibia after I year follow up.

(I) Clinical photo of the patient after I year follow up.

(J) Patient with knee extension contracture 100.

(K) Patella traction with ankle.

(L) Patella traction after 10 days.

(M) Patella traction after 14 days.

(N) Radiographic view of right knee $>90^{\circ}$.

(O) Final follow up extension view.

(P) Final follow up flexion view.

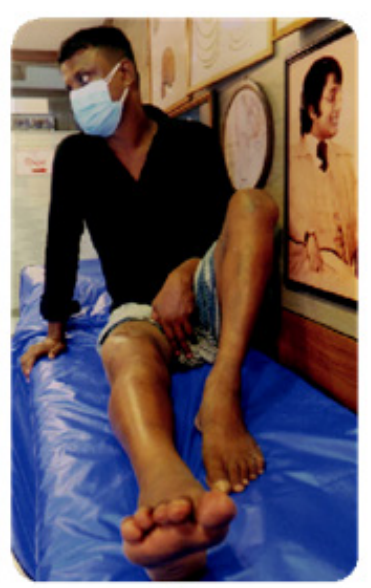

A

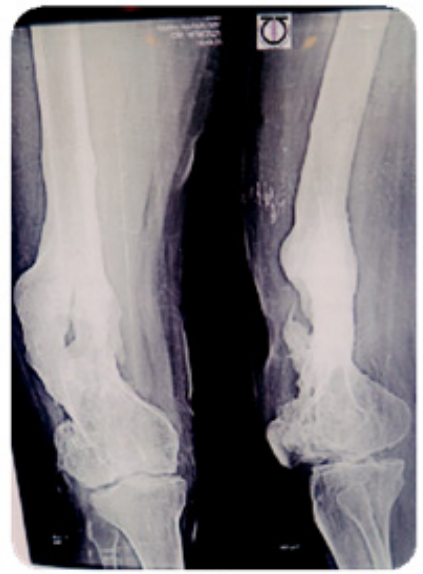

B

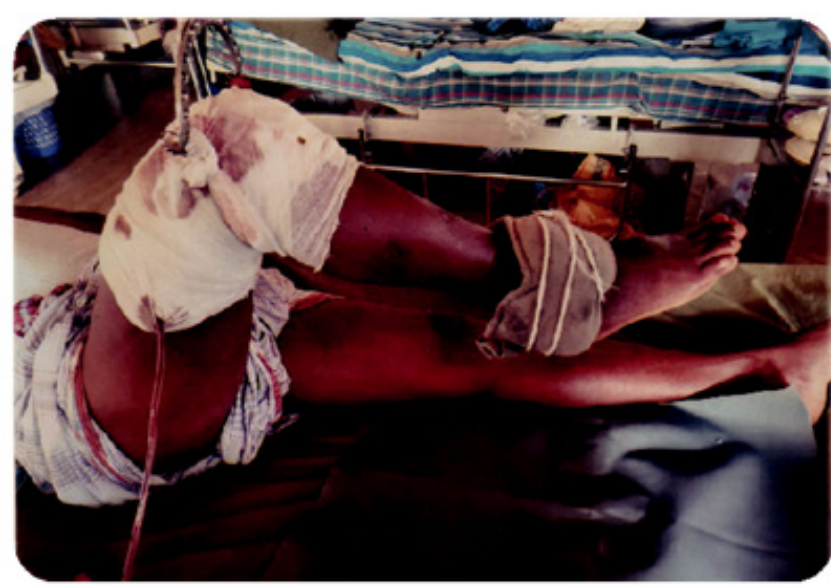

C

Citation: Bari MM, Shahidul I, Kalam AMA, et al. Modified Judet's Quadricepsplasty with patella traction for extension contracture of knee. MOJ Orthop Rheumatol. 202I;13(5):II5-I20. DOI: 10.15406/mojor.2021.13.00560 


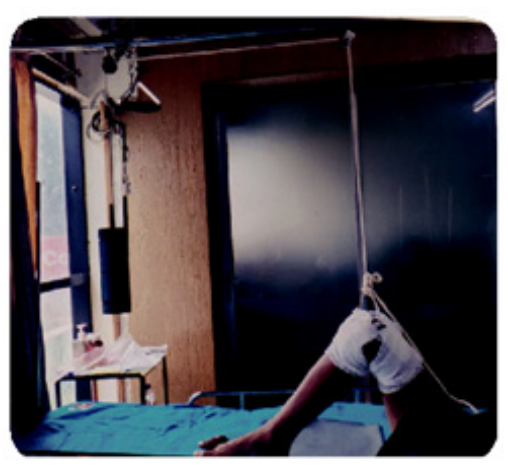

D

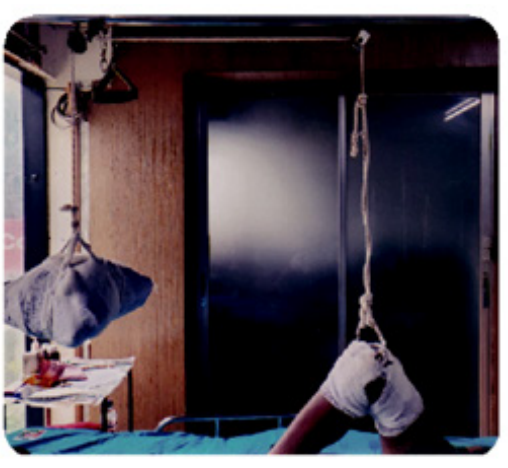

E

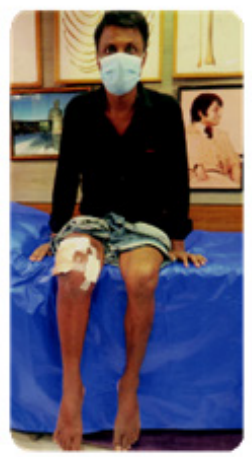

F

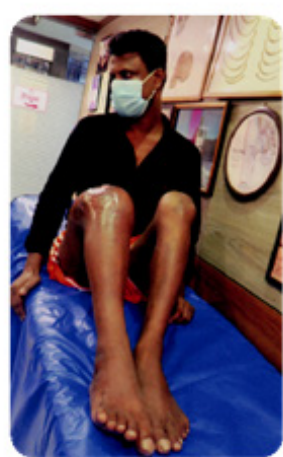

G

Figure 238 years old man, Right knee extension contracture.

(A) Patient with right knee extension contracture before surgery.

(B) Radiograph of right knee extension contracture before surgery.

(C) Patella traction and $1.5 \mathrm{~kg}$ ankle weight.

(D) Patella traction after 5 days.

(E) Patella traction after 10 days.

$(\mathrm{F}, \mathrm{G})$ Final follow up, flexion achieved $>100^{\circ}$.

\section{Acknowledgments}

None.

\section{Conflicts of interest}

The authors declare no conflicts of interest.

\section{References}

1. Paley D. Principles of deformity correction. Knee extension contracture. Orthopedics. Springer, 2000;563-567.

2. Bari MM. A color atlas of limb lengthening, surgical reconstruction and deformity correction by Ilizarov technique. 2013;p. 193.

3. Bari MM, Islam S, Shetu NH, et al. Judet's Quadricepsplasty for Extension Contrac-ture of the Knee (Sti Knee). MOJ Orthop Rheumatol. 2015;2(6):202-206.
4. Sprague NF, O'Connor RL, Fox JM. Arthroscopic treatment of postoperative knee broarthrosis. Clin Orthop Relat Res. 1982;166:165172.

5. Judet R, Judet J, Lord G. Results of treatment of sti ness of the knee caused by arthrolysis and disinsertion of the quadriceps femoris. Mem Acad Chir (Paris). 1959;85:645-654.

6. Lee DH, Kim TH, Jung SJ, et al. Modified Judet quadricepsplasty and Ilizarov frame application for sti knee after femur fractures. $J$ Orthop Trauma. 2010;24:709-715.

7. Giannoudis PV. Treatment of bone defects: bone transport or the induced membrane technique. Injury. 2016);47(2):291-292.

8. Nicoll EA. Quadricepsplasty. J Bone Joint Surg Br. 1963;45:483-490. 